\title{
The Influence of edaphic factors on the level of some physiological parameters for Lycium shawii in Taba Protected Area, Egypt.
}

\author{
Abd El-Monem M. Sharaf ${ }^{1}$, Mahmoud R. Sofy ${ }^{1}$,A. Abdullah ${ }^{2}$ \\ ${ }^{I}$ (Botany and Microbiology Dept. Faculty of Science, Al-Azhar Univ. Cairo, Egypt.) \\ ${ }^{2}$ (Nature Conservation Sector (NCS), Egyptian Environmental Affairs Agency (EEAA).)
}

\begin{abstract}
The aim of this article is assess the influence of environmental factors (especially edaphic) on the level of some physiological characteristics of plant communities in Taba Protected Area (Taba PA), South Sinai region. The Taba Protected Area (TPA) is one of Egypt's largest protected, about $2850 \mathrm{~km} 2$ (Lat. $29^{\circ} 32^{\prime}$ $N$, Long. $34^{\circ} 46^{\prime}$ E, Alt. $500 \mathrm{~m}$ a.s.l.),In International Protection Category III (In accordance with IUCN). Results showed that edaphic factors have an important role at variation in biochemical contents of plant communities within the selected wadis. The soils of study area, as desert soils (Arid soils), where soil properties vary over quite small distances, the causes of this variation due to some environmental factors such as gradient on the elevation, temperature, and rainfall between different locations..Four samples of Lycium shawii were collected from four studied locations. Evaluation of present methods used for analyzing the major biochemical contents (Soluble Carbohydrate, Water Soluble protein, Proline and Photosynthetic Pigments). Results were statistically analyzed by using One-way ANOVA and Post hoc-LSD tests (the least significant difference). In this study, prominent variation was recorded as regards the biochemical constituents of the plant among the different wadis.
\end{abstract}

Keywords: Edaphic factors, Lycium shawii,Taba PA.

\section{Introduction}

Edaphology is the study of influence of soils on plants and other living things.The Edaphic or Soil Factor is important because of the intimacy of contact between the plant and soil through the root system, and that both the plant and soil are strongly influenced by each other.Physical, chemicaland biological interactions that occur between plants and thesurrounding environment of the soil are the most complex experiencedby land plants(Powlson et al., 2011).

Soils of South Sinai, as desert soils (Arid sols), are characterized by spatial heterogeneity, where soil properties vary over quite small distances. The causes of this heterogeneity include variation in plant cover, vegetation composition, slope, and topography. (Schlesinger et al., 1996 and Moustafa and Zayed, 1996), show that soils of the South Sinai are gravelly in wadis and plains, rocky at mountains in surface, sand to loamy sand in texture, alkaline, non-saline to slightly saline. They are characterized by low content of essential nutrients and CEC.

Soils of mountainous landforms are shallow in depth but rich in silt and clay, and different soil nutrients, (Kassas, 1952) of rough sand texture, which characterized by low content of organic matter, and poorness of many essential soil nutrients such as N, P, and K (Balba, 1995). Soil pH, EC, silt and clay content are the most important indicators of soil quality, and represent driving variables in the soil system, influencing the availability of soil nutrients and controlling the coverage and structure of vegetation.

Environment inadequate conditions promoted by abiotic factors such as water, temperature, salt, and mineral elements can provoke reductions in growth and development in plants, disorders in physiological, biochemical, and molecular behaviors, besides yield losses in several crops (Tan et al., 1999; and Oliveira et al., 2009a).As a consequence, inhibition of photosynthesis, metabolic dysfunction, and damage of cellular structures contribute to growth perturbances, reduced fertility, and premature senescence. Different plant species are highly variable with respect to their optimum environments, and a harsh environmental condition, which is harmful for one plant species, might not be stressful for another (Larcher, 2003; Munns and Tester, 2008). This is also reflected in the multitude of different stress-response mechanisms.

Zeid (1992) \& Hussein (1999) suggested that increasing sugar content can play a role in osmoregulation, which increase the capacity of roots to absorb water from the soil, while the polysaccharides as well as the total carbohydrate declined with the deficiency of water supply.(Kemble and MacPherson 1954), numerous studies have shown that the proline content in higher plants increases under different environmental stresses. The pigment contents could be regarded as a criterion for photosynthetic activities (Sestak, $1967 \&$ Raafat et al., 1971). Batanouny etal. (1991) reported that there is a relationship between the photosynthetic pathway and the ecological conditions in the habitat of a particular species. 
Lyciumshawii Roem. \& Schult. Is a thorny perennial small tree or shrub that belongs to the Solanaceae family. It grows along sandy stone ridges. It has purple, sometimes white, trumpet - like flowers and sharp thorns. The leaves are elliptical and congested in closed clusters (Omar $\boldsymbol{e t}$ al., 2007).The flowers are produced during March to April in its natural environment and throughout the year in irrigated soil. The fruits are globular, many seeded, red to orange berries which are edible and somewhat sweet. It provides honey for wild bees and food and shelter for wild birds and animals (Sudhersan et al., 2003).In Yemen, the pounded leaves of this shrub have been used as a cure for eye ailments. Livestock eat new growth on the plant. Habitats include gravel plains and foothills up to 4,000 feet as well wadis. Plant associates growing nearby often include Acacia tortilis.

\subsection{Study Area}

\section{Materials and Methods}

Taba protected area is the fifth component of the South Sinai Protected Area Network. TPA is situated in the Southeast part of Sinai and is a part of the upper Sinai massif. It is located between $33^{\circ} 55^{\prime}$ to $34^{\circ} 50^{\prime}$ east, $28^{\circ} 52^{\prime}$ to $29^{\circ} 36^{\prime}$ North and Alt. 100 to $1150 \mathrm{~m}$ a.s.l. The study area (Map, 1) involves wadi systems. Taba has an extremely high recreational, conservational and scientific value, which is currently being compromised by human activities. It includes a wide variety of landscape features supporting a high diversity of habitat types and biological components.

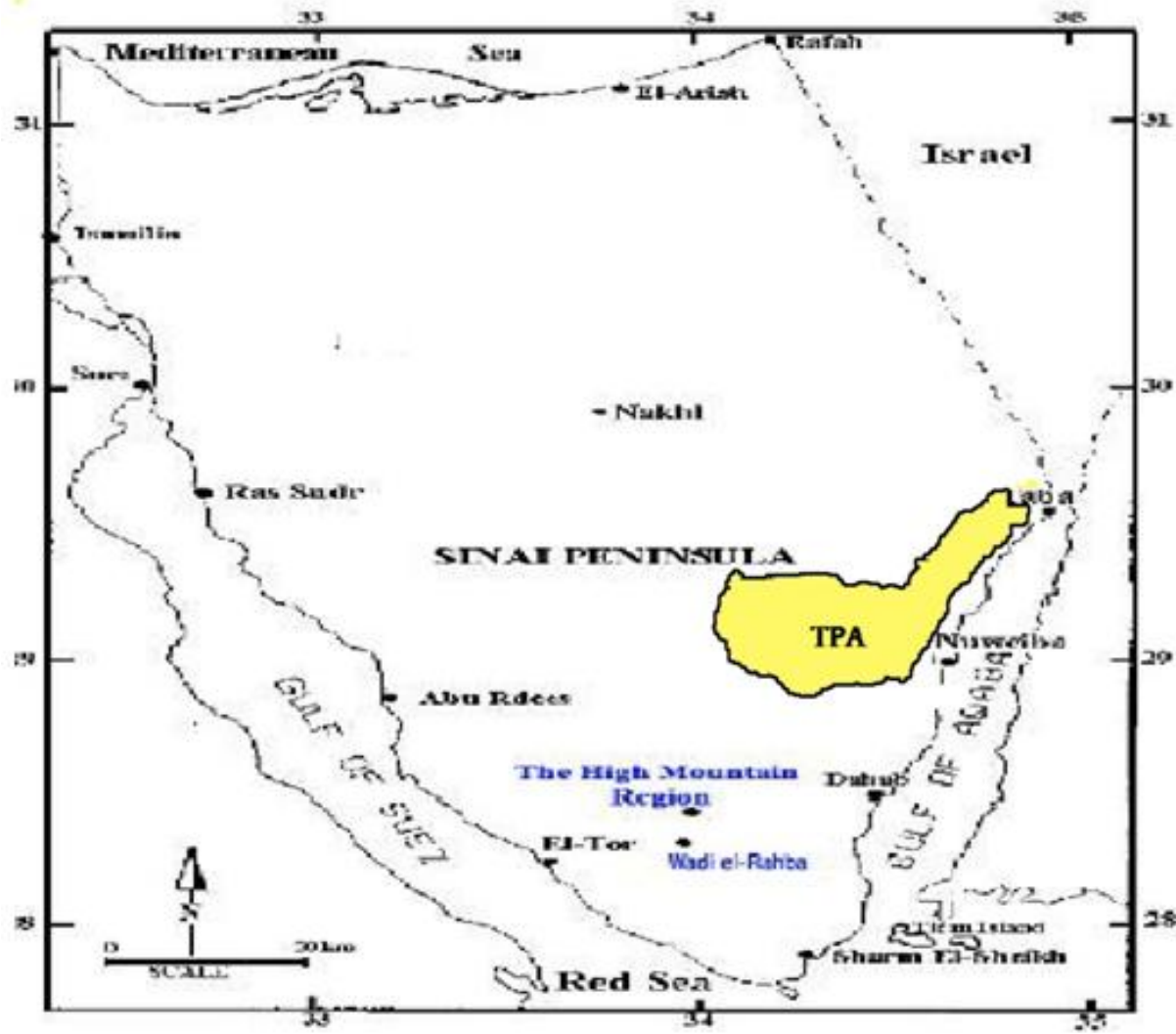

Figure 1: Sinai Peninsula map within the TPA area.

Four Wadis were selected for this study, especially altitude range and must represent the protectorate area. The first is Wadi EL Mora located between $850 \mathrm{~m}$ to $1100 \mathrm{~m}$ altitude. The second is Wadi El Zalaga located between $700 \mathrm{~m}$ to $1050 \mathrm{~m}$ altitude. The third is Wadi Ghazala which include two Part located between $300 \mathrm{~m}$ to $650 \mathrm{~m}$ altitude. And the fourth is Wadi Watier which located between $100 \mathrm{~m}$ to $400 \mathrm{~m}$ altitude(Map, 2). Cloudiness in the TPA is very low, has long summer (April Early November) and short winter (December to March). Summer temperature on land may reach $45 \mathrm{c}$.Rainfall in the studied area is about $22 \mathrm{~mm}$ per year, although exceptionally rainy years with as much as $70 \mathrm{~mm}$ rainfall may occur. Flash floods through major wadis (in winter) transport terrestrial material into the Gulf of Aqaba, resulting in large deltas and incision of submarine canyons. Annual evaporation rates on land are three times as high as along the Mediterranean shore.Relative humidity in shore localities averages 30-55\%. Wind direction is predominantly from the north (approx. 50\% frequency) and from the northeast) approx. 20\% frequency). A minor northwestern component, 
particularly in winter is present, while winds from the south are subordinate. Average wind speed is about 10-15 knots. Southerly winds in excess of 20 knots were observed mainly in winter.

\subsection{Soil samplingand Methodology}

Soil samples were collected during the work, from all the thirty-one stands for the determination of their physical and chemical characteristics. The surface samples (excluding the surface crust) were taken from the depth of $20 \mathrm{~cm}$.Physical characteristics, Soil texture was determined by using a series of sieves: fine gravel $(2 \mathrm{~mm})$, coarse sand $(500 \mu \mathrm{m})$, fine sand $(212 \mu \mathrm{m})$, silt $(106 \mu \mathrm{m})$ and clay $(53 \mu \mathrm{m})$. These samples were then taken for the laboratory, weighed and dried to constant weights at $105^{\circ} \mathrm{C}$. The difference between the fresh and oven dry weights of each sample was considered to represent the moisture content and was expressed as percentage of the oven dry weight (Jackson, 1967).

Chemical properties, Five hundred $\mathrm{ml}$ of distilled water was added to $100 \mathrm{~g}$ of air - dried soil (with a 2 $\mathrm{mm}$ sieve), and were shaken for two hours. The heavier particles were allowed to settle, and the supernatant liquid was decanted by filtration. After repeated filtrations, clear soil solution was obtained to analysis the $\mathrm{pH}$, EC, T.D.S, Org. matter, CaCO3, Ca ++, Mg++ ,HCO3, Cl and SO4(Jackson, 1967).

\subsection{Plant sampling and Methodology}

Four wadis which under study as shown in Map 2. The selection of tested samples was depending upon the following criteria:

1- The presence of target species within all locations.

2-The target species has importance environmental and economic high value.

At each site three species were collected to reflect the amount of metabolic contents. Samples (leaves) collected during one seasons at (April to May, 2014). The starting material for estimation of carbohydrates and nitrogenous constituents was the dried plants. The plant material was rapidly dried in an oven at $75^{\circ} \mathrm{C}$ to constant weight and then ground to a fine powder.These samples were taken for the physiological parameters testing (Water soluble protein,Soluble Carbohydrate's, Proline and Photosynthetic Pigments) according to (Lowery et. al., 1951 andBates et. al., 1973).

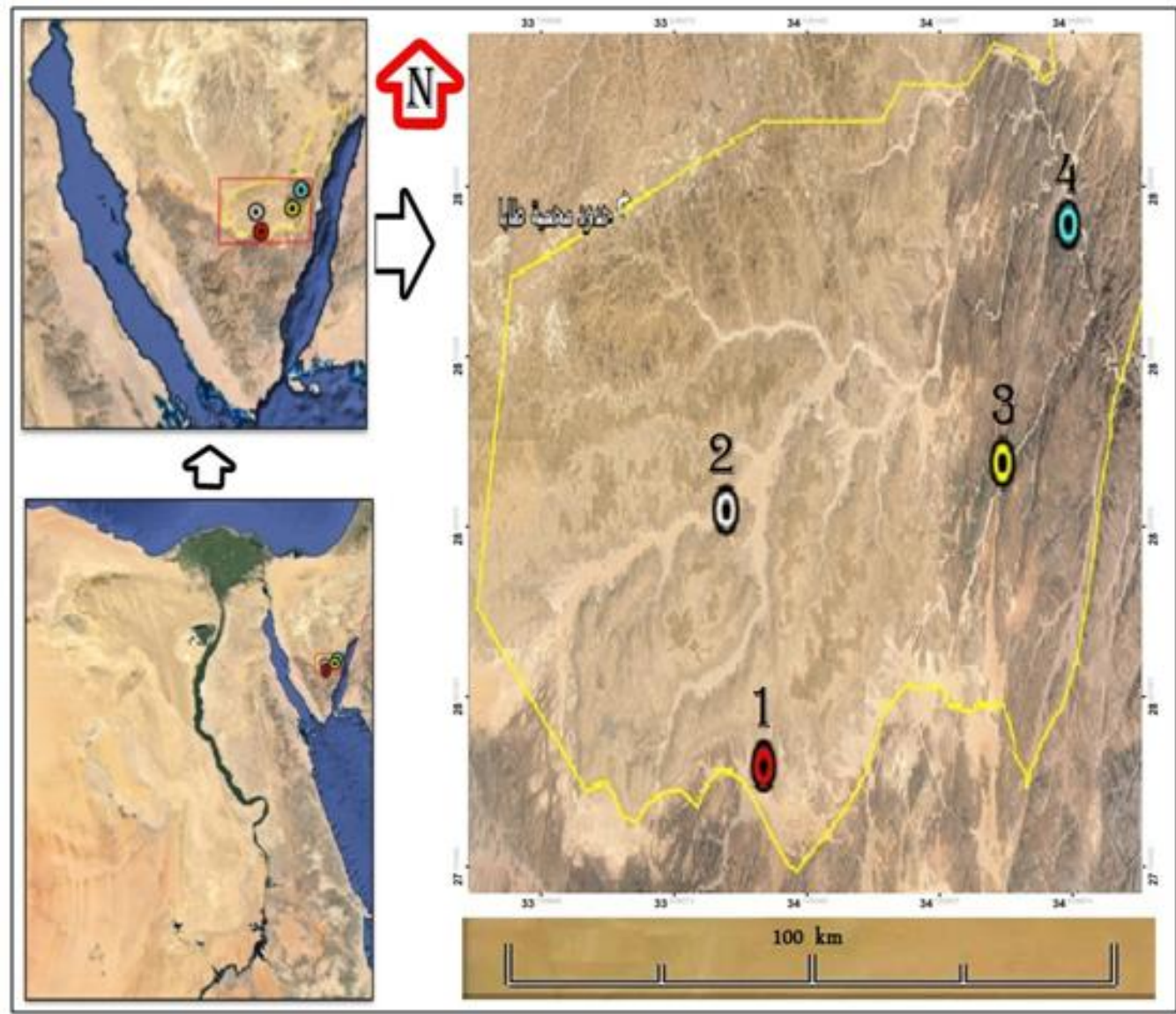

Figure 2: Location map of study area, 1- W. El Mora, 2- W. El Zalaga, 3- W. Ghazala and 4- W. Watier. 
The Influence of edaphic factors on the level of some physiological parameters for Lycium shawii in..

1.1 Soil analysis

\section{Results and Discussion}

Physical characteristics, Variations among the four Wadis in the average of soil physical properties were recorded as follow: Results showed variation among the four Wadis which studies in average of soil texture, Wadi El Zalaga and Wadi Gazala are sandy loam, and Wadi El Mora is Lomy sand, While Wadi Watier is Lomy soil texture. Moisture content showed variation among the 4 Wadis, Wadi El Mora and W. Watier present the highest value (1.44\%) and W. El Zalaga present the lowest one (1.21\%). While Wadi Ghazala presents $1.27 \%$.( Fellow Table -1).

Table 1. Physical properties of soil samples collected within the study area

\begin{tabular}{|c|c|c|c|c|c|c|c|c|c|c|}
\hline L.no & L.name & $\begin{array}{l}\text { Water } \\
\text { Content }\end{array}$ & $\begin{array}{l}\text { Fine } \\
\text { gravel }\end{array}$ & Sand & Silt & Clay & \%Sand & \%Silt & \%Clay & Texture \\
\hline 1 & $\begin{array}{l}\text { Wadi El Mora ( } \pm 922 \\
6 \mathrm{~m} \text { a.s.l.) }\end{array}$ & 1.44 & 5.84 & 79.20 & 11.16 & 3.80 & 84.11 & 11.79 & 4.10 & $\begin{array}{l}\text { Lomy } \\
\text { Sand }\end{array}$ \\
\hline 2 & $\begin{array}{l}\text { Wadi } \text { El Zalaga } \\
( \pm 881 \text { m a.s.l. })\end{array}$ & 1.21 & 0.28 & 66.87 & 22.39 & 10.46 & 67.05 & 22.46 & 10.49 & $\begin{array}{l}\text { Sandy } \\
\text { Lomy }\end{array}$ \\
\hline 3 & $\begin{array}{l}\text { Wadi Ghazala ( } \pm 491 \\
\text { m a.s.l.) }\end{array}$ & 1.27 & 6.43 & 72.60 & 14.95 & 6.01 & 77.78 & 15.75 & 6.46 & $\begin{array}{l}\text { sandy } \\
\text { loam }\end{array}$ \\
\hline 4 & $\begin{array}{l}\text { Wadi Watir }( \pm 262 \mathrm{~m} \\
\text { a.s.l.) }\end{array}$ & 1.44 & 2.96 & 53.32 & 24.33 & 19.40 & \begin{tabular}{|l|}
55.25 \\
\end{tabular} & 25.00 & 19.75 & Lomy \\
\hline
\end{tabular}

Chemical properties of soil showed great variation among the different location according to elevation ranks. Results found that soil $\mathrm{pH}(8.66,8.89,8.84$ and 8.76), $\mathrm{HCO} 3$ values $(3.21,2.95,3.14$ and 2.79), and organic matter values $(12.21,11.45,12.06$ and 11.94) increased with elevation while CaCo3, CL, SO4 and EC decreased with elevation without Location Wadi El Mora (Fig 3).

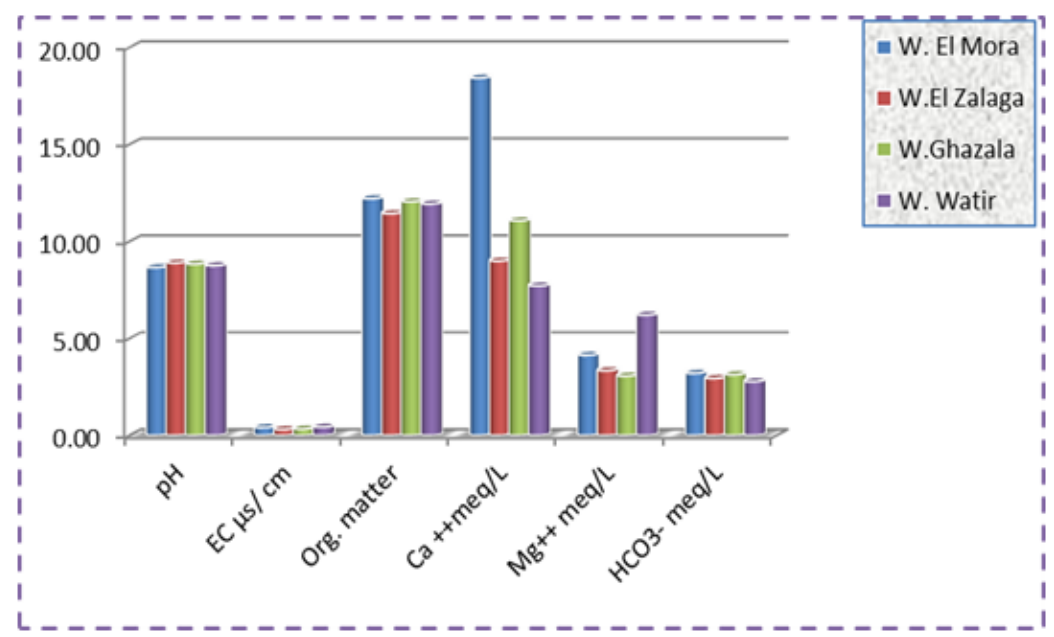

Figure --. Chemical properties of average soil among different locations.

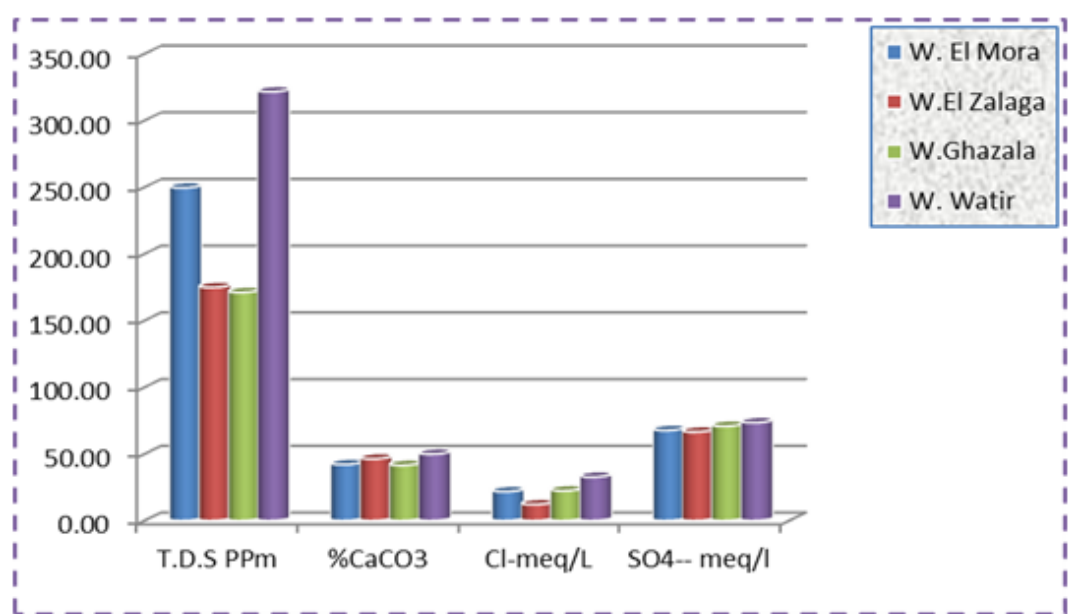

Figure 3: Chemical properties of average soil among different locations. 
The Influence of edaphic factors on the level of some physiological parameters for Lycium shawii in..

\subsection{Plant chemical analysis}

Results derived from the chemical analysis of plant species were managed and illustrated separately within and among locations (Wadi El Mora, Wadi EL Zalaga, Wadi Ghazala and Wadi Watier). At each site one sample op plant species (Lycium shawii Roem. \& Schult) was collected to reflect the amount of metabolic contents. From statistical analysis, we found that there are highly significant differences between plantchemical contents, Protein, Carbohydrate's, Proline and Chlorophyll A content but Total Chlorophyll B ( $\mathrm{F}=9.329, \mathrm{P}=$ NS),(Table 2).

Table 2. Results derived from one-way analysis of variance (ANOVA) of some physiological parameters for $L$. shawiispecies among different locations. Each value is mean for 3 replicates \pm standard error of means. It means in not significantly different according to LSD. ${ }^{* * *}=$ significant at $\mathrm{P}<0.001$ and $\mathrm{NS}=$ non-significant at $\mathrm{p}>$ 0.001

\begin{tabular}{|c|c|c|c|c|c|c|}
\hline \multirow[t]{2}{*}{ Location Names } & W.EI Mora & $\begin{array}{l}\text { W.EL } \\
\text { Zalaga }\end{array}$ & W.Ghazala & W.Watier & \multirow[t]{2}{*}{$\mathbf{F}$} & \multirow[t]{2}{*}{ Sig. } \\
\hline & $\pm 9226 \mathrm{~m}$ a.s.l. & \pm 881 m a.s.l. & \pm 491 m a.s.l. & $\pm 262 \mathrm{~m}$ a.s.l. & & \\
\hline Total soluble protein & $22.15 \pm 0.06$ & $23.14 \pm 0.02$ & $27.64 \pm 0.22$ & $23.42 \pm 0.03$ & 399.943 & **** \\
\hline $\begin{array}{l}\text { Soluble } \\
\text { Carbohydrate's }\end{array}$ & $2.93 \pm 0.03$ & $4.11 \pm 0.06$ & $1.89 \pm 0.04$ & $3.31 \pm 0.06$ & 345.871 & $* * *$ \\
\hline Total Proline content & $2.93 \pm 0.02$ & $1.64 \pm 0.01$ & $1.72 \pm 0.00$ & $2.88 \pm 0.08$ & 288.053 & **** \\
\hline Total Chlorophyll A & $1.46 \pm 0.03$ & $2.99 \pm 0.05$ & $1.21 \pm 0.01$ & $2.45 \pm 0.16$ & 92.509 & **** \\
\hline Total Chlorophyll B & $0.31 \pm 0.02$ & $0.39 \pm 0.08$ & $0.04 \pm 0.00$ & $0.26 \pm 0.05$ & 9.329 & NS \\
\hline Total Chlorophyll A+B & $1.77 \pm 0.02$ & $3.38 \pm 0.13$ & $1.25 \pm 0.01$ & $1.25 \pm 0.01$ & 219.545 & $* * *$ \\
\hline
\end{tabular}

Chemical analysis were shown that, total soluble Carbohydrates, and all pigment's contents (Chl a \& $\mathrm{Chl} \mathrm{b)} \mathrm{represent} \mathrm{the} \mathrm{highest} \mathrm{value} \mathrm{in} \mathrm{Wadi} \mathrm{El} \mathrm{Zalaga} \mathrm{during} \mathrm{Species} \mathrm{growth.} \mathrm{And} \mathrm{on} \mathrm{the} \mathrm{other} \mathrm{hand,} \mathrm{W.} \mathrm{El}$ Zalaga recorded less value in Proline contents. From these results, it is clear to us that the W. El Zalaga is the best distribution site for Lycium shawii. Because W. El Zalaga is the suitable site for highest metabolic production.

\section{Correlations detection between different metabolic contents for $L$. shawii:}

From Table 3 and Figure 4, we extract that during species growth; total soluble carbohydrate showed positively correlated with all Pigments contents. But; total soluble protein negatively correlated with all metabolic contents (total soluble carbohydrate, proline, chlorophyll a and chlorophyll b). It's shown that there are great variations in metabolic correlation that may reach to be in the reverse way, and this may be results from the variation in locations and environmental factors.

Table 3. Bivariate Pearson correlations between water soluble proteins, the total soluble carbohydrate, proline and pigment parameters for L. shawii.

\begin{tabular}{|l|l|l|l|l|l|l|}
\hline & Protein & Carbohydrates & Proline & Chl_A & Chl_B & Chl_AB \\
\hline Protein & 1 & & & & & \\
\hline Carbohydrates & $-.745-^{* *}$ & 1 & & & & \\
\hline Proline & $-.585-^{*}$ & .021 & 1 & & & \\
\hline Chl_A & -.472 & $.932^{* * *}$ & -.264 & 1 & & \\
\hline ChI_B & $-.809-^{* *}$ & $.784^{* *}$ & .218 & $.606^{*}$ & 1 & \\
\hline Chl A+B & -.407 & $.776^{* *}$ & -.486 & $.787^{* *}$ & $.594^{*}$ & 1 \\
\hline$* *$ Correlation is significant at the 0.01 level (2-tailed). \\
\hline \\
\hline *Correlation is significant at the 0.05 level (2-tailed). \\
\hline
\end{tabular}

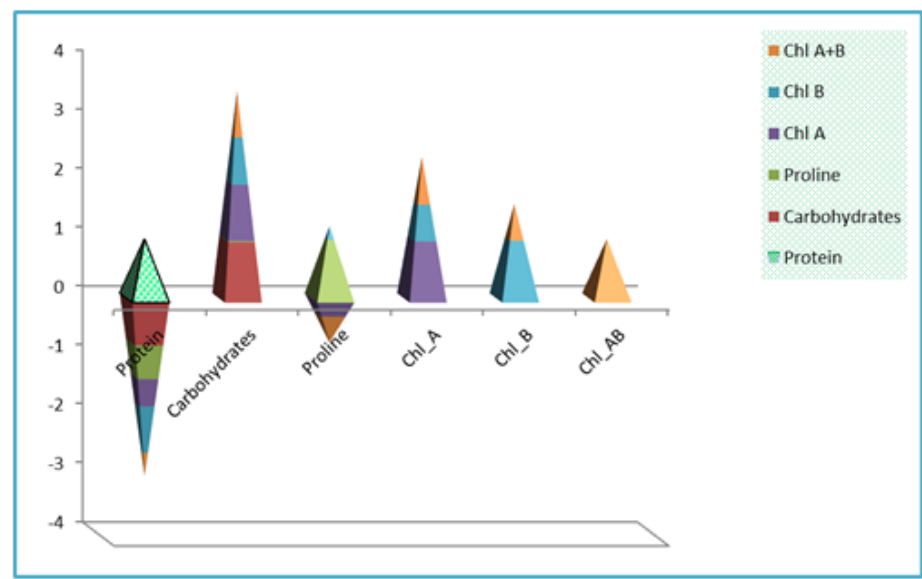

Figure 4. Correlation relationship between different metabolites for L. shawii. 


\section{Conclusion}

Regarding to the previous results, we can summarize the major conclusions for this study as; it was found that heterogeneity at ecological variables (special edaphic factor) lead to change in biochemical contents to plants. We found that environment inadequate conditions promoted by abiotic factors such as water, salt, and mineral elements can provoke reductions in growth and development in plants, disordersphysiological and biochemical contents. The variation on soil characters plays a great role in the variation of the biochemical contents.Statistical analysis of the obtained results showed variation in total carbohydrate contents among different wadies and this may come from variation in water stress which may be due to the decrease in photosynthetic process beside an increase of respiration in different plant species.We record close relationship between the growth stage and the different habitats as regards the contents of chlorophyll a, chlorophyll $b$ as well as chlorophyll $\mathrm{a}+\mathrm{b}$ contents. In this regard according to (Batanouny et al., 1991) reported that there is a relationship between the photosynthetic pathway and the ecological conditions in the habitat of a particular species.This variation on physiological parameters can be used ineconomic issue, that we can help local communitiesto detect the time and place where they can collecttheir plants for commercial use or for grazing.It is very urgent to use this study in the coming planning process within the Taba PA to reduce the negative impact of overgrazing by allowing to local community grazing in some wadis and the closure of others in different years. So, we recommended using this study as a model for know how the condition of vital ecosystem.

\section{Acknowledgements}

We really appreciate the great effort to Management and team of Taba Protected area for their continuous support during this research. Also we thank Dr. Khaled Alam the General Manager of South Sinai Protectorates for our work facilitation.

\section{References}

[1] A. Raafat, W. Hofner, and H. Linser, 14CO2 assimilation during photosynthesis of aging bean seedling. Z. Pflanzen Physiol, 1971, 64. 22 .

[2] A.M. Balba, Management of problem soils in arid ecosystems. Lewis Publishers, CRC Press, Inc., New York. 1995, 250 pp.

[3] A.M. Moustafa, and A.M. Zayed, Effect of environmental factors on the flora of alluvial fans in southern Sinai. Journal of Arid Environments 32, 1996, 2431-443.

[4] A.R. Kemble, and H.T. MacPherson, Liberation of amino acids in perennial ray grass during wilting. Biochem. J. 58, 1954, 46-59.

[5] C. Sudhersan, M. AboEl-Nil, and J. Hussain, Tissue culture technology for the conservation and propagation of certain native plants, Journal of Arid Environments 54, 2003, 133-147.

[6] D. S. Powlson, P. J. Gregory, W. R. Whalley, J. N. Quinton, D. W. Hopkins, A. P. Whitmore, P. R. Hirsch, and K.W. Goulding, Soil management in relation to sustainable agriculture and ecosystem services. Food Policy 36, 2011, S72-S87.

[7] D. Tan, A. Wearing, K. Rickert, and C. Birch, Broccoli yield and quality can be determined by cultivar and temperature but not photoperiod in south-east Queensland. Australian Journal of Experimental Agriculture 39, 1999, 901-909.

[8] I.M. Zeid, Effect of water supply and growth regulators in chemical composition and growth on Pisum sativum. Ph.D. Thesis, Fac. Sci., El-Mnofia Uni. 1992.

[9] I.S. Bates, R.P. Waldern, and I.D. Teare, Rapid determination of free proline for water stress studies. Plant and Soil, 39, 1973, 205207.

[10] K.H. Batanouny, W. Stichler, and H. Ziegler, Photosynthetic pathways and ecological distribution of Euphorbia species in Egypt. Ocologia 87, 1991, 565-569.

[11] M. Kassas, Habitat and plant communities in the Egyptian Desert. I- Introduction. Journal of Ecology 40, 1952, 342-351.

[12] M. L. Jackson, Soil chemical analysis, Prentice-Hall of India private, New Delhi, India, 1967, 498 pp.

[13] N. Oliveira, A. Lobato, R. Costa, W. Maia, F. Santos, G. Alves, B. Brinez, H. Neves, M. Lopes, and F. Cruz, Nitrogen compounds and enzyme activities in sorghum induced to water deficit during three stages. Plant, Soil and Environment 55,2009a, 238-244.

[14] N.A. Hussein, Physiological studies on Zea mays under water stress. M.Sc., Thesis, Fac. Sci., Helwan Univ., 1999.

[15] O. H. Lowery, N. J. Rosebrough, A. L. Farr, and R. J. Randall, Protein measurement with the folin reagent. J. Biol.Chem.193, 1951, 265-275.

[16] R. Munns, and M. Tester, Mechanisms of salinity tolerance. Annu. Rev. Plant Biol. 59, 2008, 651-681.

[17] S.A. Omar, Y. Al-Mutawa, and S. Zaman, Vegetation of Kuwait, 2nd ed., Kuwait Institute for Scientific Research, Kuwait, 2007.

[18] W. H. Schlesinger, J. A. Raikes, A. E. Hartley, and others, On the spatial pattern of soil nutrients in desert ecosystems. Ecology, 7,1996, 364-374.

[19] W. Larcher, Physiological plant ecology. Springer-Verlag, Berlin, 2003.

[20] Z. Sestak, Limitations for finding a linear relationship between chlorophyll content and photosynthetic activity. Biol. Plant Acad. Sci. Bohemoslov, 8, 1967, 336-346. 